\title{
An Empirical Study on the Impact of Climate Change on Farmers' Income
}

\author{
Yanni LIU * and Shuang ZHANG \\ Northwest University, Xi'an, China; lyn@nwu.edu.cn; 535216554@qq.com \\ * Correspondence: lyn@nwu.edu.cn
}

\begin{abstract}
This article counts the climate factors into farmers' income decision function, aiming to empirically tests the impacts of climate factors and climate change on farmers' net income respectively, based on the survey data of Shanxi and Henan provinces, two major agricultural provinces in China, from 1993 to 2017. The study found that the impact of climate factors and climate change on farmers' income is structural that will affect the operational income and wage income, in turn, the net income of rural residents. The average annual temperature rise and precipitation increase have a non-linear positive impact on farmers' income. At the same time, compared with the temperature change trend, more attention should be paid to the significant beneficial impact of the increased precipitation change trend on farmers' net income. According to the research result, this paper proposes that puts forward that we should attach importance to farmers' adaptation measures to different climate change characteristics, promote new technologies and development policies, and improve the income level of rural residents through various channels.
\end{abstract}

Keywords: climate change; net income of rural residents; farmer's operational net income

JEL Classification: Q54

\section{Introduction}

As early as 1988, American meteorologist James Hansen first proposed the theory of global warming, followed by various scholars who carried out a series of discussions on the trend of temperature change. Global warming has aroused global consensus since the 20th century, especially on temperature rise, the most important feature of climate change. According to the IPCC report, the global temperature rises by about $0.2^{\circ} \mathrm{C}$ every ten years. At present, it has risen by $1 \mathrm{C}$. Following this trend, it will reach $1.5 \mathrm{C}$ between 2030 and 2052. The unfavorable climate change has caused intense attention from all countries and international organizations. In 1988, the U.N. Intergovernmental Panel on Climate Change (IPCC) came into being, becoming an important position for the public to understand the common sense of climate change. The 2018 annual report "Temperature Control of $1.5 \mathrm{C}$ " sounded a great alarm for all countries. After the 1992 U.N. Framework Convention on Climate Change, the 1997 Kyoto Protocol and the 2015 Paris Agreement have become legally binding agreements. China participated in the signing of two agreements in 2002 and 2015 and earnestly fulfilled a series of commitments. Many scholars focus on the exploration impact of climate change, presenting from the research that it will significantly affect the climate resource, as well as other aspects of social production, among them, the most obvious impact is on agriculture that is closely relied on the climate. Favorable climate can promote the growth of crops, while extreme climate can slow down the growth of crops, so climate change has become an important barrier on the development of agriculture and farmers' income.

Based on this, scholars have provided a series of deep research on the impact of climate change on agriculture, initially the impact on the yield of agricultural products stated in a large number of literatures, mainly different on the selected research methods and technical treatment. On one hand, natural scientists adopt experimental simulation and obtain data through actual or simulated experiments, with the aim of mastering the responses of different crops to different climate variables (Jiang et al. 2007; Zhang et al. 2018; Zhao et al. 2019; Liu et al. 2019).On the other hand, scholars in the economic field take econometric analysis methods to create models to predict climate change trends, estimating the relationship between climate change and agricultural production in a more systematical 
and reliable way varied with regional climate demand(Zimmermann et al. 2017; Zhou et al. 2017; Zhou et al. 2018) .It is worth noting that scholars may reach very different conclusions. At the same time, Liu et al. (2004) and Wang et al. (2009) all with the help of the Ricardian Model in the research of China's agriculture, two opposite conclusions are drawn that are whether climate change, especially temperature rise, is beneficial or harmful to agricultural economy.

Later, a few literatures focused on the impact of climate change on the price of agricultural products, showing in the research that the impact is mainly through adjusting market supply and demand. First, it will affect the yield, in turn the price of crops. Under a certain impact, for example, the continuous high temperature will cause the agricultural output reduce to a certain extent, and the shortage of supply relative to demand will lead to an increase in food prices (Thomas et al. 2019) . Second, with the formation of a globalized market, the impact will lead to price differences and trade between countries, thus creating new crop prices (Li 2017; Xie et al. 2018). Recently, scholars have turned their attention to the impact of climate change on farmers' income, and found that climate change directly affect the planting structure, crop yield and quality, and planting cost, in turn, the farmers' income. This kind of research mainly adopts three means, the first is production function, adding climate change factors to the C-D production function, establishing a new evaluation model by comparing the C-D-C model with the C-D model (Chou and Du 2006). Second, by ricardian model, Mendelsohn et al. (1994) creatively presented the variation in economic benefits caused by climate change from the land value, using US cross-sectional data, reaching the conclusion that global warming can bring economic benefits to agriculture. Scholars then successively expanded ricardian model, Deschênes and Greenstone (2007) improved the major deficiency of missing important variables in ricardian model, applying panel data to study the sensitivity of agriculture to cross-time weather variation. At the same time, in order to discuss the different impacts of short-term and longterm climate changes, Kelly et al. (2005) and others used mixed data to respectively model and analyze. Vaseghi and Esmaeili (2008) chooses the net income of wheat as the breakthrough point to demonstrate the impact of climate change on income, but it only considers the net income of the agricultural system and ignores per unit area yield. Because the unit yield can better show the impact of climate change, Chen et al. (2013) showed in the grade research on agriculture that the annual impact of air temperature on unit crop income is positive, while the annual impact of precipitation increase is negative, and holds that climate change may create potential advantages for agricultural development. Besides the test of historical facts, part of scholars takes the mechanism model to predict the future change in the simulating experiment.

Though present literatures have made theoretical and empirical studies on the impact of climate change on agricultural economic benefits, there are still some problems to be resolved. Some potential factors may be omitted, resulting in errors, leading to overestimation or underestimation of the effects of climate change on agriculture. At the same time, when the global scholars have concentrated on the study of farmers' adaptive behavior, domestic scholars still directly imitate the study of ricardian model. Refer to the above problems, this article made the relevant improvement. First, about the research method, the income decision model is modified and expanded to meet the actual Chinese condition. Next, about the research variable, the climate factors and changes are distinguished to enable the research variable selection more comprehensive in relation with other production conditions. At last, on the research angle, the adaptive adjustment farmers possibly made for long term shall be considered, so as to correctly distinguish the impact of short and long term climate change on agricultural income, providing suggestions to the government on the implementation of feasible economic and agricultural policy.

\section{Methodology}

\subsection{Method}

As the income usually conforms to the normal distribution (Shorrocks and Wan 2005), This is also confirmed by the normal test of the income variables in the data of this paper. This article chooses the income determination econometric model (Morduch and Sicular 2000), this model was first applied to 
analyze the relationship between political status and Chinese citizen's income. Then, after being extended by Cheng et al. (2014), the equation is as follows:

$$
\begin{gathered}
\ln Y_{i t}=\beta_{0}+\sum \beta_{k} H C_{i t k}+\sum \beta_{l} P C_{i t l}+\sum \beta_{m} F A_{i t m}+\sum \beta_{n} S C_{i t n}+\sum \beta_{o} E S_{i t o}+\sum \beta_{p} S P_{i t p}+ \\
\sum \beta_{q} E P_{i t q}+\sum \beta_{r} F C_{i t r}+\sum \beta_{S} C V_{i t s}+\varepsilon_{i t}
\end{gathered}
$$

Among them, $\ln Y_{i t}$ is the explained variable, which represents the logarithm of the per capita income of farmers. HC, PC, FA, SC, ES, SP, EP, FC and CV respectively represent human capital, material capital, financial capital, social capital, employment behavior, system and policy, regional economic situation, family characteristics and control variables. $\varepsilon_{i t}$ is a random disturbance term, and each group of explanatory variables is equipped with the following subdivision variables.

In the full consideration of the research object, this article will set the measurement model specifically as follows.

$$
\ln P Y_{i t}=\partial_{0}+\sum \partial_{k} X_{i t k}+\sum \partial_{l} H C_{i t l}+\sum \partial_{m} P C_{i t m}+\sum \partial_{n} E P_{i t n}+\sum \partial_{o} X_{i t o}+\varepsilon_{i t}
$$

In this model, i represents i province and t represents $t$ period. The explained variables $\ln P Y_{i t}$ represent the logarithm of farmers' per capita income, among which $X_{i t K}$ are the core explanatory variables, including average temperature and average precipitation. In this paper, the annual average temperature and precipitation in the region and their quadratic terms are used to express. and $H C_{i t l}$ 、 $P C_{i t m} 、 E P_{i t n}, C V_{i t o}$ individually represent a group of human capital variables, physical capital variables, regional economic variables and control variables, among them, the variables of human capital include the education rate and education expenditure of rural residents, the variables of material capital include cultivated land area, productive capital, total mechanical power and fixed asset investment, and the regional economic characteristics include urbanization rate and urban-rural income gap. ${ }^{{ }^{i t}}$ are random error terms.

It should be noted that take the temperature and precipitation of that year as climate factors alone can reflect the impact of external climate conditions on the net income of farmers. Therefore, we independently set up model 2 to test the impact of climate factors on the income without considering other control variables, but this reflection can 't objectively describe the climate conditions on Farmers' net income. Therefore, we introduce the change degree of temperature and precipitation as the core variables into the equation, and obtains model 3.

$$
\begin{gathered}
\ln P Y_{i t}=\partial_{0}+\sum \partial_{k} X_{i t k}+\sum \partial_{l} C V_{i t l}+\varepsilon_{i t} \\
\ln P Y_{i t}=\partial_{0}+\sum \partial_{k} X V_{i t k}+\sum \partial_{l} H C_{i t l}+\sum \partial_{m} P C_{i t m}+\sum \partial_{n} E P_{i t n}+\sum \partial_{o} X_{i t o}+\varepsilon_{i t}
\end{gathered}
$$

Here, among them, $X V_{i t k}$ indicates the change degree of climate variables, that is, the deviation between the temperature and precipitation of the province in the current year and the average level of the previous five years. The meaning of other variables and parameters is the same as that of model I,

$\mathcal{E}_{i, t}$ which is a random error term.

In a word, model 1 and model 2 are used to analyze and compare the impact of annual climate factors on the per capita net income of rural residents, and model 3 is used to analyze the impact of annual climate changes on the per capita net income of rural residents.

\subsection{Data source and variable selection}

The data used in this article are mainly from Shaanxi Statistical Yearbook, Henan Statistical Yearbook, China Rural Statistical Yearbook and the National Bureau of Statistics. The data sample interval is 1993-2017, spanning 24 years, with 72 samples. Shanxi Province and Henan Province with similar agricultural natural conditions are selected. By the end of the 2017, the rural population of the two provinces totaled 68.66 million. The cultivated land area is up to 12398.608 thousand hectares. Therefore, it has certain representativeness interpreted variable. Select the per capita net income of farmers in Shaanxi Province and Henan Province to represent the farmers' income, this is consistent 
with the literature study on the factors affecting farmers' income (Cheng et al. 2014; Vaseghi and Esmaeili 2008). The main reason is that the net income can better reflect the actual income level of farmers. Considering the adaptability of farmers to climate change, the net income can better reflect the impact. The purpose of split the net income into per capita operating income, capital income and wage income is to reflect the structural impact. Due to the different statistical caliber, the net income data selected before 2013 is the per capita net income variable, and the net income data after 2014 is derived from the per capita disposable income variable, all use rural consumer price index (CPI) which make 1978 as the base period for conversion.

Explain variables and control variables. According to the research objectives of this paper, climate variables are the core variables, owing to the temperature, precipitation and their changes will have a huge impact on agricultural production, and then affect the income of farmers. We consider not only the general absolute climate variables of temperature and precipitation and add the square terms of temperature and precipitation to study whether there is a U-shaped change relationship, but also the impact of relative climate variables (the changes of temperature and precipitation). The calculation method mainly refers to Feng (2017).

Based on the classical economic growth theory, there are many factors that affect income, among which capital, labor force and regional characteristics are the most important three. According to the theory of Schultz (1961), human capital includes the quantity and quality of labor force. This paper measures the quality of labor force by the proportion of education above junior high school in the province. Unlike other scholars, the data of six lag in the current period are selected considering the lag effect of education. The quality of labor is also reflected in the level of health, given Shaanxi Province and Henan province belong to different development areas, they pay different attention to education, we adopt the sum of "education and training" and "medical treatment" in per capita consumption expenditure as the current level of physical and mental health to reflect the input gap of labor force in per capita situation. As far as capital input is concerned, it can be divided into material capital and financial capital (mainly according to Gao and Yao 2006). The most important capital related to farmers' income is land, this is also the core of Ricardo Model (Mendelsohn et al. 1994). Therefore, planting area is used to measure the sustainable input of land elements, On the other hand, because the samples studied in this paper are inland areas, the capital invested in production and the total mechanical power can well represent the impact of capital investment. The original value of per capita productive fixed capital and fixed capital investment can also represent the external production investment of the two areas. Finally, considering that even if there are similar agricultural conditions, regional factors are still important factors restricting farmers' income, this paper uses the commonly used urbanization rate and urban-rural income gap to represent regional development, the calculation method of these two variables is consistent with the existing literature.

Table 1. Statistical variable description.

\begin{tabular}{|c|c|c|c|}
\hline Variable & Meaning & Mean value & Standard deviation \\
\hline \multicolumn{4}{|l|}{ Explained variable } \\
\hline $\begin{array}{l}\text { Net income per capita of } \\
\text { farmers }\end{array}$ & $\begin{array}{l}\text { Average net income per farmer } \\
\text { yuan per person })\end{array}$ & 821.6105 & 592.7557 \\
\hline $\begin{array}{l}\text { Per capita operational } \\
\text { net income of farmers }\end{array}$ & $\begin{array}{c}\text { Average net income per person } \\
\text { from operation (yuan per person) }\end{array}$ & 329.2594 & 337.3551 \\
\hline $\begin{array}{l}\text { Per capita wage net } \\
\text { income of farmers }\end{array}$ & $\begin{array}{l}\text { Average net income per person } \\
\text { from wages (yuan per person) }\end{array}$ & 299.1622 & 218.6893 \\
\hline $\begin{array}{l}\text { Per capita capital net } \\
\text { income of farmers }\end{array}$ & $\begin{array}{l}\text { Average net income of farmers } \\
\text { from property investment (yuan } \\
\text { per person) }\end{array}$ & 19.31506 & 7.66171 \\
\hline
\end{tabular}




\begin{tabular}{|c|c|c|c|}
\hline $\begin{array}{l}\text { Annual average } \\
\text { temperature }\end{array}$ & $\begin{array}{l}\text { Annual average temperature of the } \\
\text { province }\left({ }^{\circ} \mathrm{C}\right)\end{array}$ & 16.18646 & 15.68569 \\
\hline $\begin{array}{l}\text { Annual average } \\
\text { temperature change }\end{array}$ & $\begin{array}{l}\text { Difference between provincial } \\
\text { average temperature and five-year } \\
\text { average temperature }\left({ }^{\circ} \mathrm{C}\right)\end{array}$ & 0.5275 & 0.865068 \\
\hline $\begin{array}{l}\text { Annual average } \\
\text { precipitation }\end{array}$ & $\begin{array}{c}\text { Annual average precipitation in the } \\
\text { province }(\mathrm{mm})\end{array}$ & 828.0169 & 768.3429 \\
\hline $\begin{array}{l}\text { Annual average } \\
\text { precipitation change }\end{array}$ & $\begin{array}{l}\text { Difference between provincial } \\
\text { average precipitation and five-year } \\
\text { average precipitation }(\mathrm{mm})\end{array}$ & 11.41541 & 164.7153 \\
\hline \multicolumn{4}{|l|}{ Human capital variable } \\
\hline Education rate & $\begin{array}{l}\text { Education rate above junior middle } \\
\text { school lagging behind six periods } \\
\text { in the province }\end{array}$ & 61.50417 & 12.02476 \\
\hline $\begin{array}{l}\text { Education expenditure } \\
\text { of rural residents }\end{array}$ & $\begin{array}{l}\text { "Education and training" and } \\
\text { "medical treatment" expenditure of } \\
\text { rural residents' consumption }\end{array}$ & 207.9287 & 195.9783 \\
\hline \multicolumn{4}{|l|}{ Material capital variable } \\
\hline Cultivated land area & $\begin{array}{l}\text { Total cultivated area of province } \\
\mathrm{mu} \text { ) }\end{array}$ & 9198.369 & 4743.489 \\
\hline Productive capital & $\begin{array}{c}\text { Original value of productive fixed } \\
\text { capital per capita at the end of the } \\
\text { year (yuan) }\end{array}$ & 6369.409 & 3385.218 \\
\hline Total mechanical power & $\begin{array}{l}\text { Mechanical power input a year in } \\
\text { the province (Million kilowatts) }\end{array}$ & 4667.69 & 3749.469 \\
\hline $\begin{array}{l}\text { investment in fixed } \\
\text { assets }\end{array}$ & $\begin{array}{l}\text { investment in fixed assets of rural } \\
\text { farmers a year in the } \\
\text { province(Billion yuan) }\end{array}$ & 311.949 & 267.7923 \\
\hline \multicolumn{4}{|l|}{$\begin{array}{l}\text { Regional economic } \\
\text { conditions }\end{array}$} \\
\hline Urbanization rate & $\begin{array}{l}\text { Proportion of urban population to } \\
\text { total population }\end{array}$ & 0.39024 & 0.134298 \\
\hline $\begin{array}{l}\text { Income gap between } \\
\text { urban and rural areas }\end{array}$ & $\begin{array}{l}\text { Proportion of urban per capita } \\
\text { disposable income to rural per } \\
\text { capita disposable income }\end{array}$ & 28.00047 & 32.41569 \\
\hline
\end{tabular}

\subsection{Panel stability test}

In this paper, LLC and IPS are selected to carry out unit root test. In this test, the per capita net income of farmers is logarithmized to reduce the volatility of variables. When the unit root test results are inconsistent, the data can be deemed unstable, as the results shown in Table 2. It can be seen that the data after the first-order difference of variables is stable, and after the panel cointegration test, variables present a cointegration relationship.

Table 2. Panel stability test result.

\begin{tabular}{cllcc}
\hline \multirow{2}{*}{ Variable } & \multicolumn{2}{c}{ Original sequence } & \multicolumn{2}{c}{ First difference series } \\
& LLC & IPS & LLC & IPS \\
\hline Annual average temperature & $-4.38179^{* * *}$ & $-3.81527^{* * *}$ & $-7.60464^{* * *}$ & $-7.90523^{* * *}$ \\
The quadratic of annual average & $-7.39621^{* * *}$ & $-7.80268^{* * *}$ & $-7.39621^{* * *}$ & $-7.80268^{* * *}$ \\
temperature & $-6.27575^{* * *}$ & $-6.27575^{* * *}$ & $-12.8790^{* * *}$ & $-12.3634^{* * *}$
\end{tabular}




\begin{tabular}{|c|c|c|c|c|}
\hline $\begin{array}{l}\text { The quadratic of annual average } \\
\text { precipitation }\end{array}$ & $-6.30668^{* * *}$ & $-5.69426^{* * *}$ & $-7.71665^{* * *}$ & $-8.48414^{* * *}$ \\
\hline Urbanization rate & 1.26363 & 1.56262 & $-3.66843^{* * *}$ & $-3.49521^{* * *}$ \\
\hline Total mechanical power & $-2.64819^{* * *}$ & $-2.14902^{* *}$ & $-3.54805^{* * *}$ & $-2.25515^{* *}$ \\
\hline $\begin{array}{l}\text { Income gap between urban and } \\
\text { rural areas }\end{array}$ & $-5.44351^{* * *}$ & $-6.54505^{* * *}$ & $-3.33056^{* * *}$ & $-5.60924^{* * *}$ \\
\hline $\begin{array}{c}\text { Education rate above junior } \\
\text { middle school }\end{array}$ & $-2.93258^{* * *}$ & -1.20253 & $-6.07884^{* * *}$ & $-6.09022^{* * *}$ \\
\hline $\begin{array}{l}\text { Education expenditure of rural } \\
\text { residents }\end{array}$ & -0.70230 & 0.78079 & $-3.01156^{* * *}$ & $-3.73602^{* * *}$ \\
\hline $\begin{array}{l}\text { Investment in fixed assets of } \\
\text { rural farmers }\end{array}$ & -0.22713 & 1.26595 & $-3.29396^{* * *}$ & $-2.44536^{* * *}$ \\
\hline Cultivated land area & -1.33688 & -0.50332 & $-4.44042^{* * *}$ & $-4.61456^{* * *}$ \\
\hline $\begin{array}{l}\text { Original value of productive } \\
\text { fixed capital }\end{array}$ & -0.21576 & 1.20155 & $-3.19790^{* * *}$ & $-3.57828^{* * *}$ \\
\hline $\begin{array}{l}\text { Net income per capita of } \\
\text { farmers }\end{array}$ & -0.52237 & 1.59557 & $-3.61181^{* * *}$ & $-2.47397^{* * *}$ \\
\hline
\end{tabular}

2 The superscript ${ }^{* * *}, * *,{ }^{*}$ are significant at the level of $1 \%, 5 \%$, and $10 \%$, respectively.

\section{Results}

\subsection{Climate change and farmers' net income}

Since this paper adopts panel data, the fixed effect model is selected after the test. As the regression results shown in Table 3, except for Model 2, the adjusted $\mathrm{R}^{2}$ is greater than 0.9 , indicating that the model as a whole has great explanatory power.

In terms of climate variables, the set temperature and precipitation variables are significant in the three models, indicating that climate variables are important factors affecting farmers' income level. Model 2 analyzes the impact of climate variables on farmers' net income without controlling variables. The annual average temperature has a positive impact on farmers' net income and passes the $10 \%$ significance test. The annual average precipitation has a negative impact on farmers' net income and passes the $5 \%$ significance test. From the regression results of model 2, it can be seen that the quadratic coefficient of temperature and precipitation is opposite, and the absolute value of the quadratic coefficient is small, which indicates that the average annual temperature rise and the average annual precipitation decrease have a non-linear positive impact on farmers' net income. In model 3, the regression coefficient of annual precipitation change to farmers' net income is -0.000379 . passed the significance test of $10 \%$, at the same time, the regression coefficient of annual temperature change to farmers' net income is 0.059147 , which shows that compared with the adverse effect of increasing precipitation change trend, the increasing trend of temperature change can have a greater positive impact on farmers' net income.

As far as human capital is concerned, the two sub-variables are both significant in model 1 and model 3, which shows that human capital is also an important factor affecting farmers' income level. For every $1 \%$ increase in the rate of education delayed by six periods, the income of farmers decreased by $3.7 \%$, indicating that education expenditure is still a major part of farmers' income expenditure. At the same time, for every $1 \%$ increase in current expenditure on education and medical training, the net income of farmers will increase by $0.5 \%$. Therefore, it will be greatly meaningful to pay attention to the cultivation of human capital in rural areas to improve the net income per capita in rural areas.

As far as material capital is concerned, two of the four sub-variables have passed the significance test in different degrees in different models. Among them, for each additional mu of sown area, the per capita net income of farmers will increase by $0.09 \%$, for per capita fixed capital investment increased by $1 \%$, per capita net income of farmers will increase by $2.3 \%$. This shows that increase of capital investment plays an important role in improving farmers' income, and at the same time, the dependence of farmers on land in China has decreased. 
In terms of the level of regional economic development, although the two variables are not significant, the regression coefficient of urbanization rate is the largest in the two models, which shows that in the progress of urbanization, it is a better and fast way to increase the net income of rural residents while narrowing the income gap between urban and rural residents.

Table 3. Analysis of the impact of annual climate factors and changes on per capita net income of rural residents.

\begin{tabular}{cccc}
\hline Variable & Model 1 & Model 2 & Model 3 \\
\hline Annual average temperature & 0.000332 & $0.018193^{*}$ & \\
The quadratic of annual average & $-0.010148^{* *}$ & -0.00398 & \\
temperature & & $-0.00322^{* *}$ & \\
Annual average precipitation & $-0.000936^{* *}$ & $5.19 \mathrm{E}-07^{* *}$ & \\
The quadratic of annual average & $1.43 \mathrm{E}-07^{* *}$ & & 0.333505 \\
precipitation & & & -0.000155 \\
Urbanization rate & 0.882635 & -0.001554 \\
Total mechanical power & $-5.74 \mathrm{E}-05$ & \\
areas & -0.003384 & & $-0.056224^{* * *}$ \\
Income gap between urban and rural & & & $0.006136^{* * *}$ \\
Education rate above junior middle school & $-0.037545^{* * *}$ & & $0.002190^{* *}$ \\
Education expenditure of rural residents & 0.005405 & & $0.000991^{* * *}$ \\
Investment in fixed assets of rural farmers & $0.002301^{*}$ & & $-0.000146^{* * *}$ \\
Cultivated land area & $0.000892^{*}$ & & $0.059147^{*}$ \\
Original value of productive fixed capital & -0.000151 & & $-0.000379^{*}$ \\
Temperature change & & & 1.949420 \\
Precipitation change & & & 0.975257 \\
C & $5.445869^{* *}$ & 10.47195 & 0.601841 \\
The adjusted R2 & 0.978001 & & \\
\hline
\end{tabular}

${ }^{3}$ The superscript ${ }^{* * *},{ }^{* *},{ }^{*}$ are significant at the level of $1 \%, 5 \%$, and $10 \%$, respectively.

\subsection{Climate change and farmers'net operational income}

The impact of annual climate factors and changes on rural residents' net operating is considered, in the same way the fixed effect model is also selected after passing the test. As the regression results shown in Table 4, except for Model 2, the adjusted $\mathrm{R}^{2}$ is greater than 0.9 , indicating that the model as a whole has great explanatory power.

In terms of climate variables, the set temperature and precipitation variables are remarkable in the three models, showing that climate variables are key factors affecting farmers' income level. Model 2 analyzes the impact of climate variables on farmers' net income without controlling variables. The quadratic term of annual average temperature has a positive impact on farmers' net income, passing the significance test of $1 \%$, and the first degree is not significant, which indicates that there is an inverse $\mathrm{U}$ relationship between annual average temperature and farmers' net income from operations. The impact of annual precipitation on farmers' net income is positive, has passed the $5 \%$ significance test, meanwhile the coefficient of the quadratic term of annual precipitation is negative, and has passed the $5 \%$ significance test. In model 1, the coefficients of average annual temperature and its quadratic term, and average annual precipitation are positive and significant. From the regression results of models 1 and 2, it can be seen that the coefficients of temperature quadratic term and precipitation are positive, and the absolute values of the coefficients of quadratic term are large. These indicate that with the increase of average annual precipitation, the farmers' operational income presents increasing trend, and the average annual temperature rise has a non-linear positive impact on the farmers' net income. In the model 3, the regression coefficient of annual precipitation change to farmers' net income is 0.000192 , passed the significance test of $1 \%$, the average annual temperature change coefficient is larger 
but not significant, showing that the increase of temperature change may cause positive impact, so the increasing trend of precipitation change will have benefit on farmers' net income.

As per the human resources, segmentation variable is notable in model 2 and model 3, indication the human resources are key to farmers' operational income level. Different from the impact of education delayed for six periods on the per capita net income of farmers, for every $1 \%$ increase in education rate, the operational income of farmers will $1.5 \%$ increase by $1.5 \%$. It shows that the larger the proportion of education, the more favorable it is for rural residents to carry out various business activities such as agricultural production. In terms of material capital, only the net present value of productive capital among the four segmentation variables is significant at the significance level of $1 \%$. For every $1 \%$ increase in net present value of productive fixed capital per capita, the net income per capita of farmers will increase by $0.01 \%$. This shows that the value of productive fixed assets owned by residents can better promote the improvement of operational income of rural residents in the current period compared with the investment in fixed assets in the current period. From the perspective of regional economic development level, the urbanization rate is significant in the two models, and its regression coefficient is the largest, which indicates that the degree of urbanization is also an important factor affecting the net operating income of rural residents.

Table 4. Analysis of the impact of annual climate factors and changes on per capita net operating income of rural residents.

\begin{tabular}{cccc}
\hline Variable & Model 1 & Model 2 & Model 3 \\
\hline Annual average temperature & $0.002687^{* *}$ & -0.002334 & \\
The quadratic of annual average & $0.006787^{* * *}$ & $0.017340^{* * *}$ & \\
temperature & $0.000302^{*}$ & $0.001680^{* *}$ & \\
Annual average precipitation & $-4.22 \mathrm{E}-08$ & $-2.70 \mathrm{E}-07^{* *}$ & \\
The quadratic of annual average & & \\
precipitation & $0.569712^{*}$ & & $0.780915^{* *}$ \\
Urbanization rate & $-1.27 \mathrm{E}-05$ & & $-1.13 \mathrm{E}-05$ \\
Total mechanical power & 0.001165 & & 0.001251 \\
Income gap between urban and rural areas & $0.01492^{* * *}$ & & $0.02367^{* * *}$ \\
Education rate above junior middle school & 0.000372 & & 0.001081 \\
Education expenditure of rural residents & -0.00056 & & -0.0005 \\
Investment in fixed assets of rural farmers & -0.00015 & & $-0.00021^{*}$ \\
cultivated land area & $0.000128^{* * *}$ & & $0.000102^{* * *}$ \\
Original value of productive fixed capital & $0.002687^{* *}$ & & 0.015908 \\
Temperature change & & & $0.000192^{* * *}$ \\
Precipitation change & & $5.823414^{* * *}$ \\
C & $4.309198^{* * *}$ & 2.063895 & 0.937361 \\
\hline The adjusted R2 & 0.959272 & 0.205273 & \\
\hline
\end{tabular}

${ }^{4}$ The superscript ${ }^{* *},{ }^{* *},{ }^{*}$ are significant at the level of $1 \%, 5 \%$, and $10 \%$, respectively.

\subsection{Climate change and farmers'net wage income}

The impact of annual climate factors and changes on rural residents' net wage income is considered, in the same way the fixed effect model is also selected after passing the test. As the regression results shown in Table 5, except for Model 2, the adjusted $R^{2}$ is greater than 0.9 , indicating that the model as a whole has great explanatory power.

In terms of climate variables, the set temperature and precipitation variables only have higher significance in model 2, and their coefficients and significance are the same as the impact of climate variables on farmers' operational income. From the models 1 and 2, if the first degree of temperature change is not significant, the quadratic term of annual average temperature will have a positive effect on farmers' net income, and has passed the significance test of $1 \%$, which shows that there is an inverse 
U relationship between annual average temperature and farmers' wage income. In model 3, the regression coefficient of annual precipitation change to farmers' wage net income is 0.001741 , passing the significance test of $5 \%$, but the annual average temperature change is not significant. It indicates that the greater the change trend of annual precipitation, the more favorable the increase of farmers' wage net income. This may because of the drastic change of precipitation that drives farmers to give up business activities.

In terms of human capital, the segmentation variable is significant in model 3 . For every $1 \%$ increase in the education rate, the operational income of farmers will increase by $5.5 \%$, indicating that the larger the proportion of education, the more favorable it is for rural residents to obtain employment and wage income. In terms of material capital, only the net present value of productive capital among the four segmentation variables is significant at the level of $1 \%$ under the two models. For every $1 \%$ increase in net present value of productive fixed capital per capita, the net income per capita of farmers will increase by $0.02 \%$, while the current fixed asset investment is adverse to the increase of wage income. This shows that once the current investment in fixed assets is made, the probability of residents engaging in production and business activities will increase, and the ratio of working will decrease relatively. Based on this, possession of more productive fixed assets will promote their participation in working activities. In terms of regional economic development, the urbanization rate is not remarkable in both models, but the regression coefficient of urbanization rate is the largest, which indicates that urbanization degree is also an important factor affecting rural residents' net income.

Table 5. Analysis of the impact of annual climate factors and changes on wage net income of rural residents.

\begin{tabular}{|c|c|c|c|}
\hline Variable & Model 1 & Model 2 & Model 3 \\
\hline Annual average temperature & -0.00064 & -0.00823 & \\
\hline $\begin{array}{c}\text { The quadratic of annual average } \\
\text { temperature }\end{array}$ & $0.011301^{* * *}$ & $3.66 \mathrm{E}-02^{* * *}$ & \\
\hline Annual average precipitation & 0.000428 & $0.00331^{* *}$ & \\
\hline $\begin{array}{c}\text { The quadratic of annual average } \\
\text { precipitation }\end{array}$ & $-5.92 \mathrm{E}-08$ & $-5.26 \mathrm{E}-07^{* *}$ & \\
\hline Urbanization rate & 0.373231 & & 0.554217 \\
\hline Total mechanical power & $-5.86 \mathrm{E}-06$ & & 0.000143 \\
\hline $\begin{array}{c}\text { Income gap between urban and rural } \\
\text { areas }\end{array}$ & 0.003242 & & 0.000469 \\
\hline $\begin{array}{c}\text { Education rate above junior middle } \\
\text { school }\end{array}$ & 0.040887 & & $0.055032^{* * *}$ \\
\hline $\begin{array}{l}\text { Education expenditure of rural } \\
\text { residents }\end{array}$ & 0.001347 & & -0.00333 \\
\hline $\begin{array}{c}\text { Investment in fixed assets of rural } \\
\text { farmers }\end{array}$ & $-0.00128^{* * *}$ & & -0.00034 \\
\hline Cultivated land area & $-4.27 \mathrm{E}-05$ & & -0.00037 \\
\hline $\begin{array}{l}\text { Original value of productive fixed } \\
\text { capital }\end{array}$ & $0.000207^{* * *}$ & & $0.000145^{* * *}$ \\
\hline Temperature change & & & -0.015884 \\
\hline Precipitation change & & & $0.001741^{* *}$ \\
\hline C & -0.299694 & -3.233161 & 6.076092 \\
\hline The adjusted R2 & 0.946989 & 0.297915 & 0.934889 \\
\hline
\end{tabular}

${ }^{5}$ The superscript ${ }^{* * *}, * *, *$ are significant at the level of $1 \%, 5 \%$, and $10 \%$, respectively.

\subsection{Climate change and farmers'net property income}

The impact of annual climate factors and changes on rural residents' net property income is considered, in the same way the fixed effect model is also selected after passing the test. As the 
regression results shown in Table 6, except for Model 2, the adjusted $\mathrm{R}^{2}$ is greater than 0.9 , indicating that the model as a whole has great explanatory power.

In terms of climate variables, the set temperature and precipitation variables have higher significance only in model 2, which shows that climate change hardly affects the property income of rural residents. As per human capital, a segmentation variable is notable in model 1 . For every $1 \%$ increase in rural residents' consumption of education and medical care, the operational income of farmers will increase by $0.39 \%$, indicating that the larger the education expenditure, the more favorable it is for rural residents to make property investment and obtain property income. As for physical capital, only fixed asset investment among the four segmentation variables has passed the significance test at $10 \%$ level under both models. In terms of regional economic development, the urban-rural income gap has passed the significance test of $1 \%$ in both models, and the larger the urban-rural income gap is, the lower the rural residents' property net income, because the premise of fixed asset investment is to have capital. The larger the urban-rural income gap is, the lower the rural per capita disposable income is, and the lower the amount that can be invested naturally. The rural residents' wage net income be increased only when the urban-rural income gap is greatly narrowed.

Table 6. Analysis of the impact of annual climate factors and changes on the property net income of rural residents.

\begin{tabular}{cccc}
\hline Variable & Model 1 & Model 2 & Model 3 \\
\hline Annual average temperature & 0.002692 & -0.007727 & \\
The quadratic of annual average & 0.003767 & $0.053066^{* * *}$ & \\
$\quad$ temperature & & & \\
Annual average precipitation & 0.000469 & $0.003952^{* *}$ & \\
The quadratic of annual average & $-6.53 \mathrm{E}-08$ & $-6.40 \mathrm{E}-07^{* *}$ & \\
$\quad$ precipitation & & & 0.636201 \\
$\quad$ Urbanization rate & 0.863514 & & -0.000158 \\
Total mechanical power & $-7.99 \mathrm{E}-05$ & & $-0.007661^{* * *}$ \\
$\quad$ areas & $-0.008728^{* * *}$ & & 0.015006 \\
Income gap between urban and rural & & & 0.073265 \\
Education rate above junior middle school & 0.009418 & & $0.001603^{*}$ \\
Education expenditure of rural residents & $0.003937^{* *}$ & & $9.48 \mathrm{E}-05$ \\
Investment in fixed assets of rural farmers & $0.001660^{*}$ & & 0.636201 \\
Cultivated land area & $-4.67 \mathrm{E}-05$ & & 0.000222 \\
Original value of productive fixed capital & $0.000219^{* * *}$ & & 0.062122 \\
Temperature change & & & -0.137941 \\
Precipitation change & & & 0.919679 \\
$\quad$ C & 0.306601 & -8.504075 & \\
$\quad$ The adjusted R2 & 0.912565 & 0.411173 & \\
\hline
\end{tabular}

${ }_{6}^{6}$ The superscript ${ }^{* *},{ }^{* *},{ }^{*}$ are significant at the level of $1 \%, 5 \%$, and $10 \%$, respectively.

\section{Discussion and Conclusion}

on the one hand, the research results of this paper show that the average annual precipitation has a negative effect on the rural residents' per capita net income, which means that the average annual precipitation increases, the rural residents' per capita net income demonstrates a downward trend. It is consistent with the conclusion of Chen et al. (2013), the possible reason is that the selected sample is mainly cultivated with dry crops in the inland area, and the increase of precipitation is not favorable to the increase of production, which affects the per capita net income of rural residents; The change of annual precipitation has negative influence on the per capita net income of rural residents, which is consistent with the conclusion of Feng (2017), the possible reason is that there is seasonal variation in crop water demand, the degree of its reflection to the reality is reduced by the explanation of the deviation of precipitation. 
On the other hand, the second term of annual mean temperature has a negative effect on the per capita net income of rural residents, indicating that the effect of temperature on the per capita net income of rural residents is non-linear, that is the increase of temperature under other conditions unchanged, farmers' net income first increases and then decreases, which is in line with the law of cultivation. The annual mean temperature change has a positive effect on the per capita net income of rural residents, which is consistent with the conclusion of Liu et al. (2004).

In conclusion, this article applies the provincial panel data of Shanxi Province and Henan Province from 1993 to 2017. It builds a fixed effect model by expanding the income model, empirically analyzes the economic impact of climate change on the net income of rural residents in the two provinces, and identifies the key climate factors that affect the net income of farmers in the two provinces. At the same time, it decomposes the income results and studies the ways the climate change affects the per capita net income of rural residents. The study found that: (1) Climate factors and their changes have a significant impact on the net income of rural residents in the two provinces. In general, the average annual temperature rise and the average annual precipitation increase have a non-linear positive impact on farmers' net income, while the increasing trend of precipitation change will have a favorable impact on farmers' net income. (2) Climate factors mainly affect the rural residents' operational income and wages of rural residents in two provinces, in turn, the net income of rural residents. (3) Among other controlling variables, each factor has a key factor that affects the net income of rural residents in the two provinces. The higher the urbanization rate, the greater the proportion of education, and the more fixed capital investment, the more conducive to promoting the income increase of rural residents. In accordance to the above conclusions, this article suggests that farmers and local governments should pay attention to adaptive measures for different climate change characteristics. In recent years, China's agriculture-related technologies are making quick progress, with new crop varieties and agricultural production technologies emerging one after another. However, more attention should be attached to adaptation to climate change trends in the process of research and development of new crop varieties, development and popularization of new technologies. Otherwise, the positive benefits brought by scientific and technological progress to agricultural production may be greatly reduced, and farmers' operating income may be lost. For regions with obvious climate change trends, varieties that can be adapted to climate change should be adopted as far as possible.

\section{References}

Cheng Mingwang, Shi Qinghua, and Jin Yanhong. 2014. Household income level, structure and its influencing factors: Empirical Analysis Based on the micro data of the national rural fixed observation points. Quantitative economic, technological and economic research: https://doi.org/10.13653/j.cnki.jqte.2014.05.001

Chen Yongfu, Wu Zhigang, Katsuo Okamoto, Han Xinru, Ma Guoying, Chen Hsiaoping, and Zhao Jing. 2013. The impacts of climate change on crops in China: A ricardian analysis. Global and Planetary Change: 104, 6174. https://doi.org/10.1016/j.gloplacha.2013.01.005

Chou Jieming, and Du XingYe. 2006. Building a new economic climate model to evaluate the impact of climate change on Grain Yield. Climatic and Environmental Research: 03, 347-353. https://doi.org/cnki:sun:qhyh.0.200603-010

Deschênes Olivier, Greenstone Michael. 2007. The Economic Impacts of Climate Change: Evidence from Agricultural Output and Random Fluctuations in Weather. The American Economic Review: 97, 354-385. https://doi.org/10.1257/aer.97.1.354

Feng Xiaolong. 2017. Adaptive behavior of apple growers to climate change. Available online: https://kns.cnki.net/kns/detail/detail.aspx?FileName=1017101955.nh\&DbName=CDFD2017(accessed on 26 May 2017)

Gao Mengtao, and Yao Yang. 2006. Micro basis of income gap of farmers: material capital or human capital? Economic research: 2, 71-80.

Jiang Qunou, Deng Xiangzheng, Zhan Jinyan, Liu Xingquan, and Tang Xiuhua. 2007. Climate change in Huang Huai Hai Plain and its impact on cultivated land production potential. Geography and Geo-information Science: 05, 82-85. https://doi.org/10.3969/j.issn.1672-0504.2007.05.018 
Kelly David, Kolstad Charles, and Mitchell Glenn. 2005. Adjustment costs from environmental change. Journal of Environmental Economics and Management: 50, 468-495. https://doi.org/10.2307/2118029

Li Yushuang. 2017. Asymmetric transfer effect of international grain price on China's grain price: a study based on the nardl model. Comparative Economic E Social Systems: 03, 127-137. https://doi.org/cnki:sun:jjsh.0.201703-013

Liu Hui, Li Xiubin, Fischer Guenther, and Laixiang Sun. 2004. Study on the impacts of climate change on china's agriculture. Climatic Change: 65, 125-148 https://doi.org/10.1023/B:CLIM.0000037490.17099.97

Liu Yujie, Qin Ya, and Ge Quansheng. 2019. Spatiotemporal variation of maize phenology in China from 1981 to 2010 under the background of climate change. Journal of Geographical Sciences: 29, 351-362. https://doi.org/ 10.1007/s11442-019-1602-5

Mendelsohn Robert, Nordhaus William, and Shaw Daigee. 1994. The Impact of Global Warming on Agriculture: A ricardian Analysis. The American Economic Review: 84, 753-771. https://doi.org/10.2307/2118029

Morduch Jonathan, and Sicular Terry. 2000. Politics, Growth and Inequality in Rural China: Does it Pay to Join the Party. Journal of Public Economics: 77, 331-356. https://doi.org/10.1016/S0047-2727(99)00121-8

Schultz W. Thodore. 1961. Investment in human capital. The American Economic Review: 51, 1-17. https://doi.org/10.10.2307/2230051

Shorrocks Anthony, and Wan Guanghua. 2005. Spatial decomposition of inequality. Journal of Economic Geography: 5, 59-81. https://doi.org/10.1093/jnlecg/lbh054

Thomas Chatzopoulos, Ignacio Pérez Domínguez, Matteo Zampieri, and Andrea Toreti. 2019. Climate extremes and agricultural commodity markets: A global economic analysis of regionally simulated events. Weather and Climate Extremes. https://doi.org/10.1016/j.wace.2019.100193

Vaseghi Elahen, and Esmaeili Aak. 2008. Investigation of the Economic Impacts of Climate Change on Iran Agriculture: A ricardian Approach (Case study: Wheat). Journal of Science $\mathcal{E}$ Technology of Agriculture $\mathcal{E}$ Natural Resources: 45, 685-696.

Wang JinXia, Mendelsohn Robert, Dinar Ariel, Huang Jikun, Rozellee Scott, and Zhang Lijuan. 2009. The impact of climate change on China's agriculture. Agricultural Economics: 40, 323-337. https://doi.org/10.1111/j.15740862.2009.00379.x

Xie Wei, Huang Jikun, Wang Jinxia, Cui Qi, Robertson Ricky, and Chen Kevin. 2018. Climate change impacts on China's agriculture: The responses from market and trade. China Economic Review. https://doi.org/10.1016/j.chieco.2018.11.007

Zhang Kai, Wang Runyuan, Li Qiaozhen, Wang Heling, Zhao Hong, Yang Fulin, Zhao funian, and Qi Yue. 2018. The effect of increasing CO2 concentration on spring wheat production and water use efficiency in semi-arid area. Chinese Journal of Applied Ecology: 29, 165-175. https://doi.org/10.13287/j.1001-9332.201809.028

Zhao Yanxi, Xiao Dengpan, Bo Huizi, and Tao Fulu. 2019. Response and adaptation of Crop Phenology to climate change in China. Progress in Geography: 38, 224-235. https://doi.org/10.18306/dlkxjz.2019.02.006

Zhou Yingxia, Wang Quanjiu, He Bin, Zhang Jihong, and Tan Shuai. 2017. Simulation analysis of the influence of temperature and CO2 concentration on Winter Wheat Yield in Northern Shaanxi. Journal of Soil and Water Conservation: 31, 292-297. https://doi.org/10.13870/j.cnki.stbcxb.2017.05.045

Zhou Yingxia, Wang Quanjiu, Zhang Jihong, Tan Shuai, and HeBin. 2018. Simulation analysis of the impact of climate change on Winter Wheat Yield in Shaanxi Province Based on aquacrop model Research of Soil and Water Conservation: 25, 357-364. https://doi.org/10.13869/j.cnki.rswc.2018.06.051

Zimmermann Andrea, Webber Heidi, Zhao Gang, Ewert Frank, Kros Johannes, Wolf Joost, Britz Wolfgang, and Wimde Vries. 2017. Climate change impacts on crop yields, land use and environment in response to crop sowing dates and thermal time requirements. Agricultural Systems: 157, 81-92. https://doi.org/10.1016/ j.agsy.2017.07.007 